\title{
Damage Analyzing of Cargo Sidewall Boeing 737-800 in Cargo Restoration Process Using DMAIC Method at Aircraft Maintenance and Repair Company
}

\author{
Viki Aprianto ${ }^{1}$, Erry Rimawan ${ }^{2}$, Putri Gunanti ${ }^{3}$, Irfan Setyo ${ }^{4}$ \\ Department of Industrial Engineering ${ }^{1,2}$, Department of Magister Management ${ }^{3,4}$ \\ Mercu Buana University, Jakarta, Indonesia
}

\begin{abstract}
PT. GMF AeroAsia Tbk, is an aircraft repair and maintenance company, at the beginning of semester 2019 the base maintenance department found significant damage of 75 ea on the cargo side wall components during the process of cargo compartment restoration, on the basis that the writer tried to find the causes and gave suggestions for improvement using DMAIC method approach. After being analyzed using a fishbone diagram, the factors causing damage are due to lack of skill and knowledge, lack of tools, poor material quality, wrong methods, and poor lighting. After being analyzed by FMEA, lack of skills and knowlage became the dominant cause with the largest RPN value of 173 . The proposed improvements given were to schedule training and conduct mentoring programs in the field, the aim being to increase skills and knowlage transfer.
\end{abstract}

Keywords:- DMAIC, FMEA, Fishbone Diagram, Parreto Diagram.

\section{INTRODUCTION}

\section{$>$ Background}

PT. GMF AeroAsia, Tbk is a world class MRO that was built at Soekarno Hatta Airport in Tangerang, engaged in aircraft maintenance. Has 4 hangars, aircraft maintenance, one of which is hangar, 4. Hangar 4 is hangar, the largest Narrow Body in the world. This hangar is able to accommodate 15 aircraft at once and 1 hangar for painting. Customers not only from within the country but from abroad as well, sent from countries in Asia, Africa, the Middle East and even Europe.

The aircraft that will carry out the maintenance will start from the Body, Wings, Engine, Cabin and Cargo Compartment. The examination is based on the Continuous Airworthiness Maintenance Program (CAMP) and the Aircraft Maintenance Manual (AMM). If there is damage it will be recorded into Maintenance Discriepancy and Rectification (MDR). Inspections in the cargo compartment area are no less important than other areas, the cargo used to carry goods often has significant damage, especially on the sidewall and floor. Nearly every aircraft that carries out maintenance, the components are replaced with newly worn and damaged and cannot be used anymore. The following data is damage to the Boeing 737-800 aircraft cargo compartment.

\begin{tabular}{|c|c|c|c|}
\hline \multirow{2}{*}{ Bulan } & \multirow{2}{*}{ Registrasi } & Cargo Floor & Part Broken (unit) \\
\cline { 3 - 4 } & PK-GMU & 7 & Cargo Sidewall \\
\hline Januari & PK-GMH & 6 & 9 \\
\hline Februari & PK-GMW & 3 & 11 \\
\hline Maret & PK-GFN & 7 & 15 \\
\hline April & PK-GFF & 4 & 13 \\
\hline Mei & PK-GFO & 9 & 75 \\
\hline Juni & & 36 & 17 \\
\hline \multicolumn{2}{|c|}{} \\
\hline
\end{tabular}

Table 1:- Cargo Compartment Damage Table January - June 2019

Source : Data Processing

Data from Cargo Compartment Damage in January June 2019 in Table 1.1 shows that there is quite a lot of damage to the sidewall cargo section, which is 17 units in June, Boeing 737-800 PK-GFO aircraft. So it is necessary to do research on the root causes, as well as repair solutions related to the damage. Improvements in this study using the DMAIC method. As research in previous journals conducted by Caesaron (2015)[1], which uses the same method that is DMAIC to examine any damage that occurs in the BMW X3 Handling Painted Body process. So with 
the DMAIC method, it can be concluded that the most dominant damage occurring in the BMW X3 Handling Painted Body process is flex $(31.3 \%)$, chip (24.7\%), contamination (18.7\%) and scratch (13), 3\%). The research is the same as what I will examine now but the difference lies in the object of the research.

\section{Formulation of the Problem}

- What factors cause sidewall Cargo damage?

- How to repair to reduce the percentage of sidewall Cargo damage in the company PT. GMF AeroAsia, Tbk?

\section{$>$ Research Purposes}

- Knowing the factors that cause damage to Cargo Sidewall.

- Conduct an analysis of improvements in order to reduce the level of damage Cargo sidewall in the company PT GMF AeroAsia, Tbk

\section{Scope of Problem}

- Retrieval of data is only Cargo Sidewall that was damaged in the January 2019 period until June 2019.

- Research only for Boeing 737-800 aircraft types.

- The results of the research are in the form of proposals or recommendations to the company.

\section{REVIEW OF LITERATURE STUDY}

\section{$>$ Maintenance}

According to Higgins (2002)[2], maintenance is an activity that is carried out repeatedly with the aim that the equipment always has the same conditions as the initial state. Maintenance is also carried out to keep the equipment in a condition that is acceptable to its users.

\section{> DMAIC (Define, Measure, Analyze, Improve, Control)}

According to Breyfogle (2003)[3] DMAIC (Define, Measure, Analyze, Improve, Control) is a basic component of the Six Sigma methodology, which is used to improve the performance of a process by eliminating defects.

DMAIC is a systematic, scientific, and fact based process. This method eliminates production processes that are not value added, sometimes focuses on measurement, and applies the best technology for process improvement (GE, 2013)[4].

\section{FMEA (Failure Mode and Effect Analysis)}

FMEA is a way in which a part or a process that may fail to meet a specification, creates a defect or discrepancy and its impact on the customer if the failure mode is not prevented or corrected (Kenneth 2002)[5].

\section{Cause-effect Diagram}

According to Nasution (2005)[6], a Cause and Effect Diagram is a structured approach that allows a more detailed analysis to find the causes of a problem, discrepancies, and gaps that occur.

\section{Parreto Diagram}

Pareto diagram is an image that ranks data classification from left to right in the highest to lowest rank order. So that problems are found that are important to be resolved immediately (from highest to lowest ranking) (Ariani 2004)[7].

\section{Cargo Compartment}

According to Majid and Warpani (2009)[8] cargo is "All goods sent by air (airplane), sea (ship) or land (container truck) to be traded, both between regions or cities within the country and between countries (internationally) known with the term export-import. " In addition to carrying goods belonging to cargo compartment passengers are also used to keep the aircraft structure from fire (insulation).

\section{METHODOLOGY}

In this study to meet or achieve the research objectives in order to complete the final assignment, the types of data and information needed, among others:

\section{- Primary Data}

According to (Sugiyono, 2012)[9], primary data is a source of data that directly provides data to data collectors. Primary data collection in this study includes:

- Data from the FMEA questionnaire conducted by the mechanic of PT. GMF AeroAsia.

- Interview regarding the general description of the production process to the head of the production department PT. GMF AeroAsia, Tbk.

\section{Secondary Data}

According to (Sugiyono, 2012)[9], Secondary data is data obtained by reading, studying and understanding through other media sources of literature, books, and company documents. Secondary data collection in this study includes:

- Data on the number of defect Cargo Sidewall periode for January - June 2019.

- And supporting data such as historical aircraft maintenance before.

\section{Research Step}

The research steps are presented in the form of Flowchart as follows: 


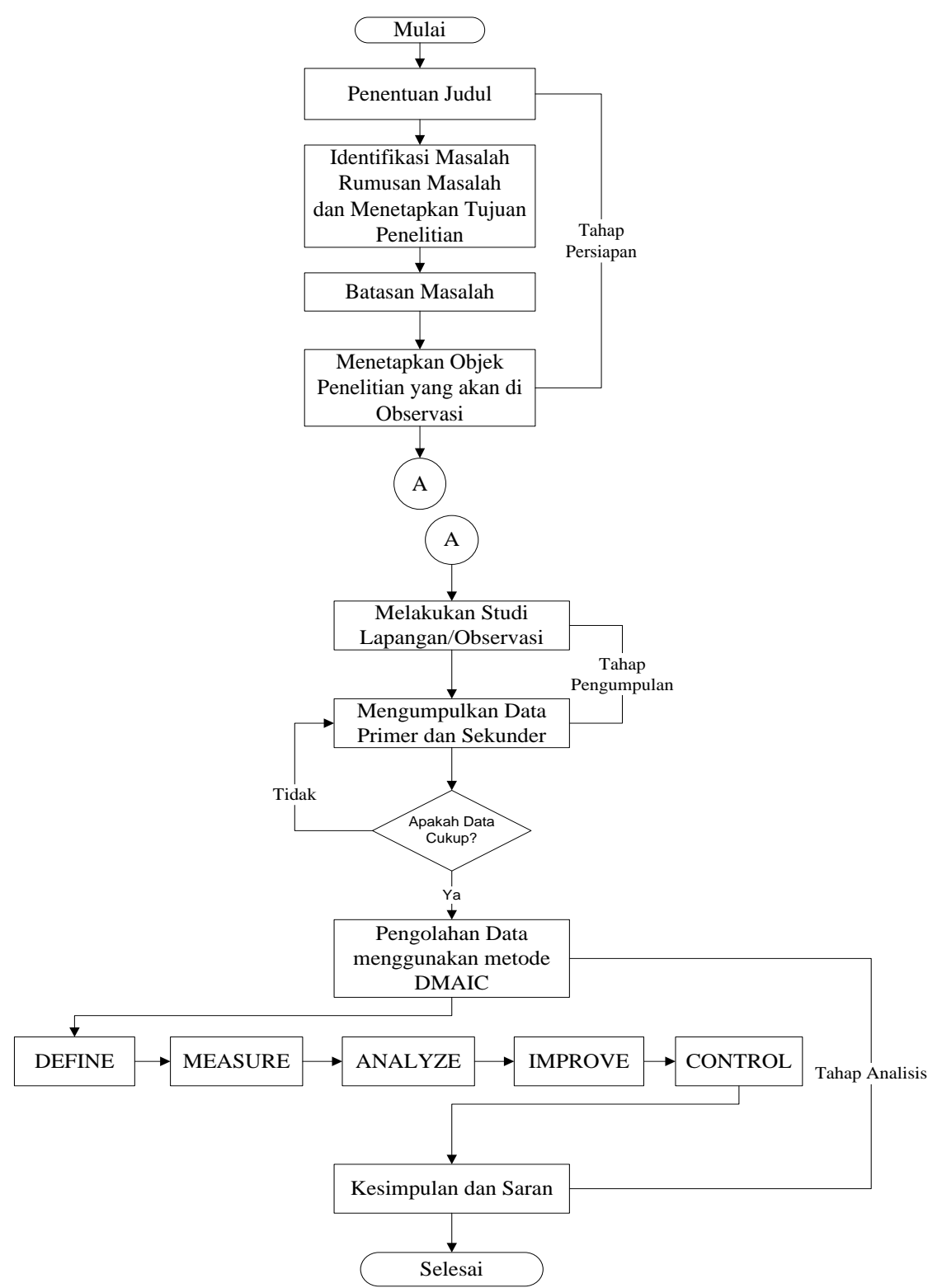

Fig 1:- Research Flow Chart Diagram

\section{RESULT}

\section{Exsisting Failure Data}

After observing directly in the production section for a period of 6 months there were several defects that occurred to Cargo Sidewall. The data is taken and recorded per aircraft in the Inspection Cargo Compartment phase, from all Cargo Sidewalls totaling 18 ea per aircraft there are several damaged ones including

\begin{tabular}{|c|c|c|c|c|c|c|c|c|}
\hline \multirow{2}{*}{ Bulan } & \multirow{2}{*}{ Registrasi } & \multicolumn{9}{|c|}{ Jenis Defect } & \multicolumn{2}{c|}{ Total } \\
\cline { 3 - 9 } & & Tear & Hole & Scratch & Dent & Peel Off & Other & 0 \\
\hline Januari & PK-GMU & 6 & 2 & 1 & 0 & 2 & 0 & 0 \\
\hline Februari & PK-GMH & 5 & 2 & 2 & 0 & 0 & 0 \\
\hline Maret & PK-GMW & 4 & 4 & 0 & 0 & 2 & 11 \\
\hline April & PK-GFN & 8 & 4 & 2 & 0 & 1 & 0 \\
\hline Mei & PK-GFF & 5 & 5 & 0 & 0 & 3 & 0 & 13 \\
\hline Juni & PK-GFO & 10 & 5 & 2 & 0 & 0 & 0 & 17 \\
\hline \multicolumn{2}{l}{ Total } & $\mathbf{3 8}$ & $\mathbf{2 2}$ & $\mathbf{7}$ & $\mathbf{0}$ & $\mathbf{8}$ & $\mathbf{0}$ & $\mathbf{7 5}$ \\
\hline
\end{tabular}

Table 2:- Table of Damages that Occur in 6 Months in 2019

Source : PT. GMF AeroAsia 
Based on the damage table data that occurred in the first semester of 2019, the largest amount of damage occurred in June, which was 17 damage with the largest number of defects, Tear 38 tear. The following is a picture of a cargo sidewall in good condition and a damaged condition.

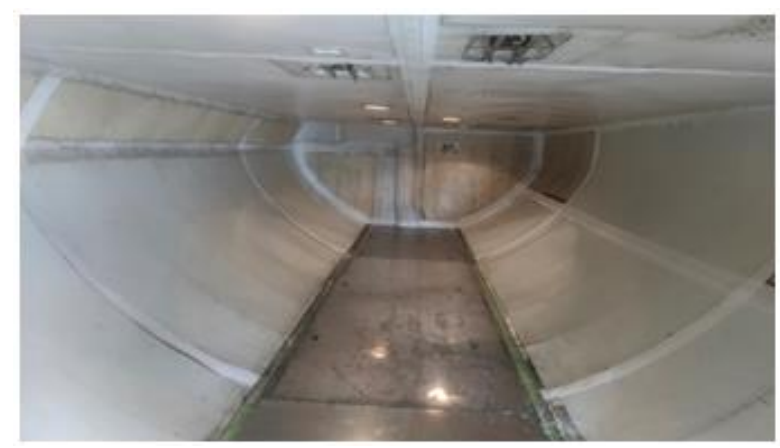

Good Condition

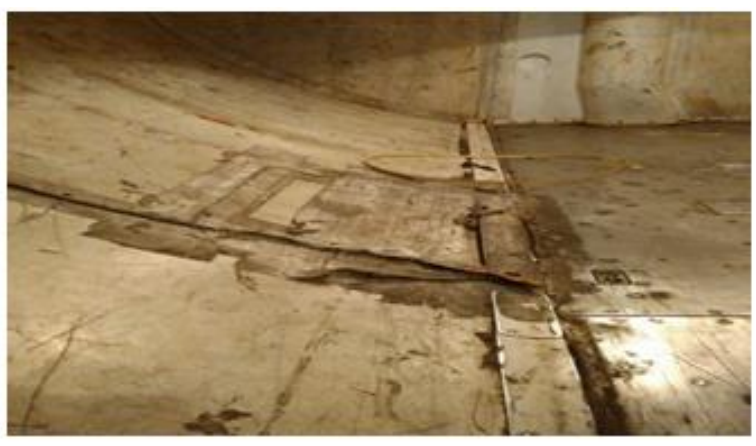

Damage Condition (Tear)

Fig 2:- Condition of Cargo Sidewall

\section{Define}

In this define phase writer use SIPOC diagram as an analysis tool. The SIPOC diagram is a process flow showing major activities or subprocesses in a business process consisting of suppliers, inputs, processes, outputs and customers (Syukron and Kholil, 2013)[10]. The SIPOC diagram presents a brief view of the workflow as follows: SIPOC (Supplier, Input, Process, Output, Costumer).

\begin{tabular}{|c|c|c|c|c|}
\hline Supplier & Input & Proses & Output & Costumer \\
\hline Composite Shop & Raw Material & Mapping & Sidewall Sheet & Production Departmant \\
\hline & Fiber Glass Sheet & Cutting & & \\
\hline & & Drilling & & \\
\hline
\end{tabular}

Table 3:- Table SIPOC

Source: Data Processing

From Table 3 we can explain that the process is carried out at the Composite Shop as a supplier and requires raw material in the form of Fiberglass sheet. After that the Raw Material will enter the process stage, namely mapping, this process traces the shape of the sidewall mold to the Raw material, after that it is cut and drilled to make a fastener hole. The output is in the form of a sidewall Cargo ready to be installed and sent to the Production Department as a Customer. Arriving at the Cargo Production Department the sidewall was installed in accordance with the Procedure (Aircraft Maintenance Manual) by a mechanic.

\section{Measure}

Measure is a phase of damage calculation based on available data, from this stage we can draw conclusions about what is the most dominant damage, so it can be analyzed in the next stage. By using the Pareto diagram tools we can see the presentation of the biggest damage.

\begin{tabular}{|c|c|c|c|}
\hline Jenis Defect & Total Defect & \% & Cumulative \\
\hline Tear & 38 & $51 \%$ & $51 \%$ \\
\hline Hole & 22 & $29 \%$ & $90 \%$ \\
\hline Peel Off & 8 & $11 \%$ & $100 \%$ \\
\hline Scratch & 7 & $9 \%$ & $100 \%$ \\
\hline Dent & 0 & $0 \%$ & $100 \%$ \\
\hline Other & 0 & $0 \%$ & $100 \%$ \\
\hline Total & 75 & &
\end{tabular}

Table 4:- Data Processing Tables use Parreto Diagrams

Source: Data Processing

Based on the results of the processed data table 4, further analysis is done using a pareto chart to find out the most influential causes that must be resolved to reduce damage. 
ISSN No:-2456-2165

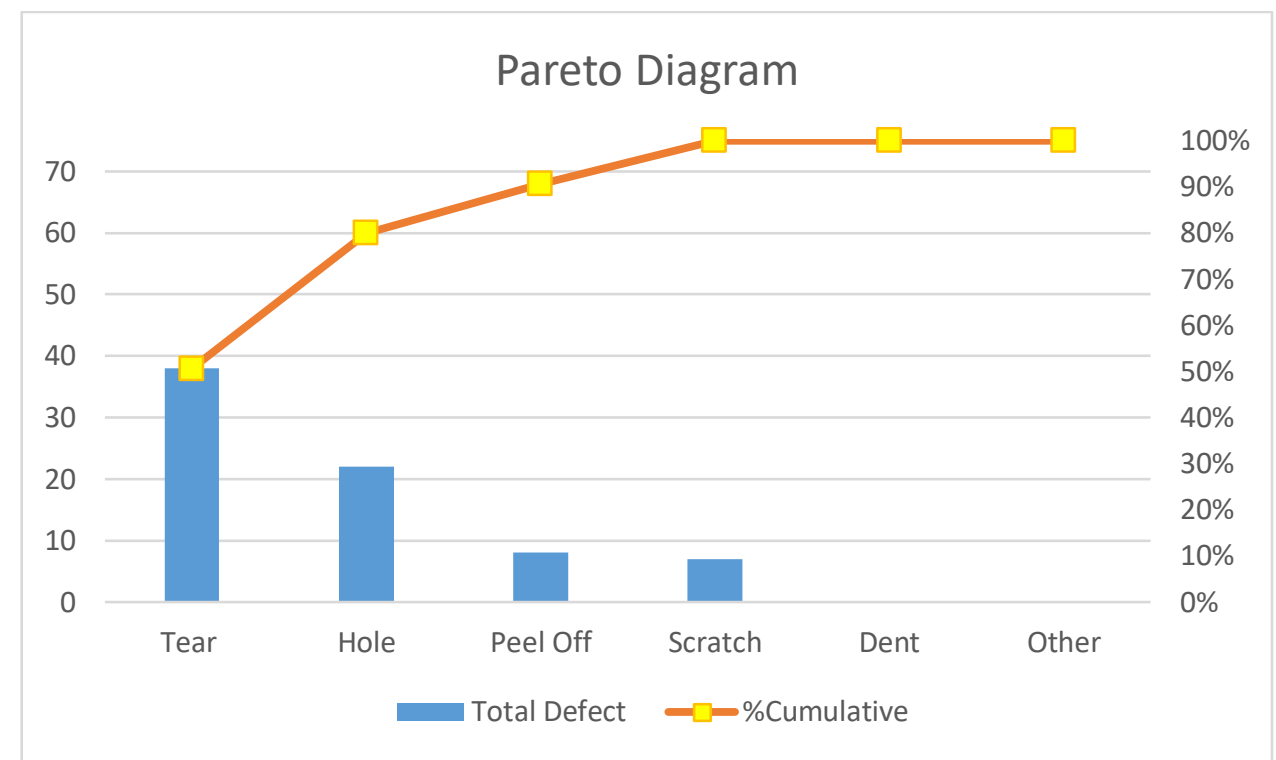

Fig 3:- Pareto Diagram Percentage of Damage Type

Analyze

Analyze (analysis) is analyzing the causal relationship of various factors that are studied to determine the dominant factors that need to be controlled. In this case we analyze the underlying causes of the sidewall Cargo damage with the most dominant damage being Tear $(51 \%)$. In this stage you can use Fishbone Diagrams (Diagram of Cause and Effect) with 4M + 1E, as follows:

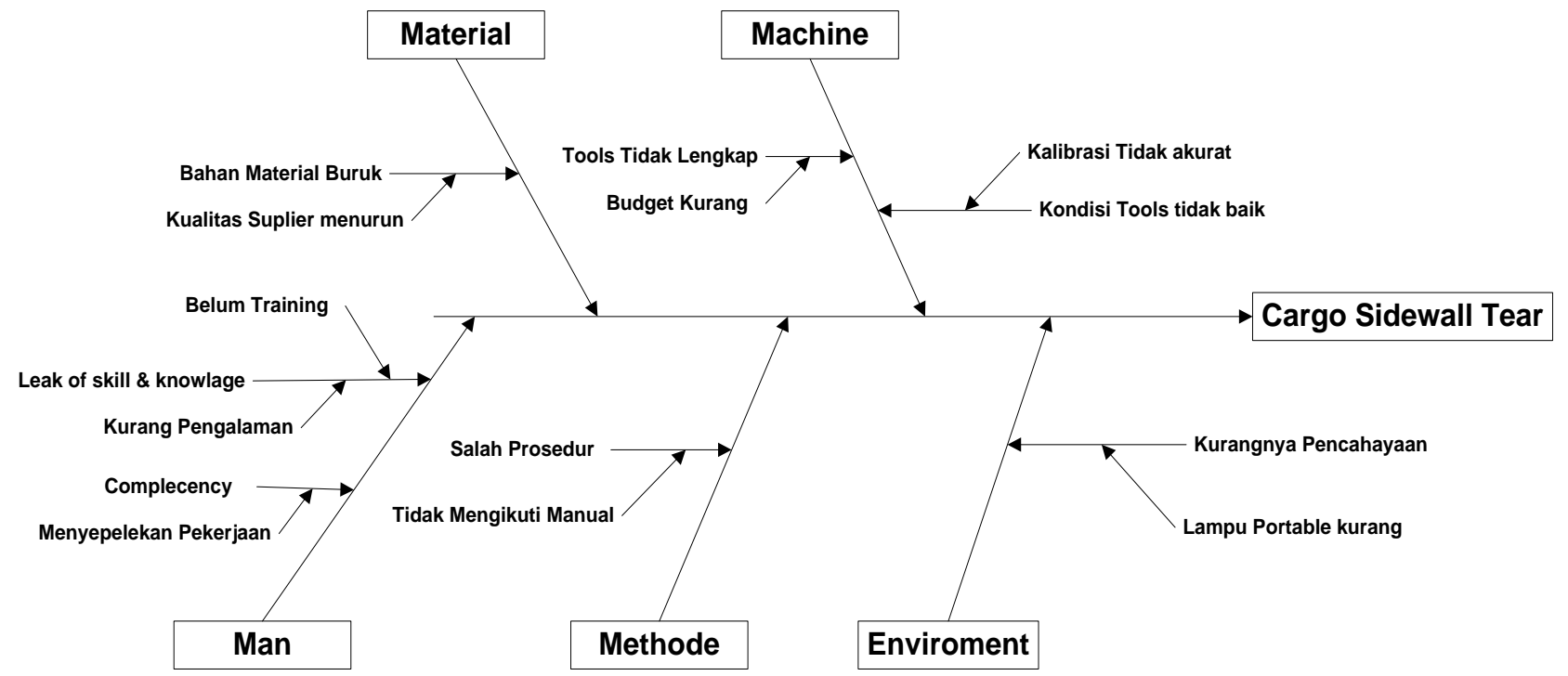

Fig 4:- Identification of Cargo Sidewall Cause Failure

From the picture above, it explains that the cause of the Cargo Sidewall Tear is caused by 5 factors, namely: Machine, material, man, method, environment. Machine factor is incomplete tools due to lack of budget and poor tool condition due to inaccurate calibration. Material factors, namely Material Meterial Poor due to supplier quality decreases. The man factor is lack of skill due to inexperience and lack of training, inaccurate due to carelessness and complacency due to underestimation of work. The method factor is procedure error due to not following the manual. The environmental factor is lack of lighting due to lack of portable lights.

\section{Improve}

After knowing several factors that cause failure of the cargo sidewall tear, we use the Failure Mode and Effect Analysis (FMEA) method to see which factors are the most dominant in producing failures based on the highest RPN value. FMEA which functions to provide a weighting on the value of Severity, Occurance, and Detection based on the potential failure, and the cause of failure to produce a Risk Priority Number (RPN) value. 
ISSN No:-2456-2165

\begin{tabular}{|c|c|c|c|c|c|c|c|}
\hline $\begin{array}{c}\text { Failure } \\
\text { Mode }\end{array}$ & $\begin{array}{l}\text { Effect Of } \\
\text { Failure }\end{array}$ & Cause Of Failure & Current Control & $S$ & $\mathrm{O}$ & $\mathrm{D}$ & RPN \\
\hline \multirow{8}{*}{$\begin{array}{l}\text { Cargo } \\
\text { Sidewall } \\
\text { Tear }\end{array}$} & \multirow{8}{*}{$\begin{array}{c}\text { Causes } \\
\text { Structure of } \\
\text { Cargo } \\
\text { Compartment } \\
\text { Corrosion, } \\
\text { Crack, and } \\
\text { Dent }\end{array}$} & Lack of Skill \& Knowlage & $\begin{array}{l}\text { Providing training to } \\
\text { technicians. }\end{array}$ & 7 & 5 & 5 & 175 \\
\hline & & Not Careful & $\begin{array}{l}\text { There is a water break to } \\
\text { increase concentration for } 10 \\
\text { minutes. }\end{array}$ & 7 & 2 & 2 & 28 \\
\hline & & Complacency & $\begin{array}{l}\text { Increase awareness of work } \\
\text { and not underestimate it. }\end{array}$ & 6 & 4 & 6 & 144 \\
\hline & & Poor quality of raw materials & $\begin{array}{l}\text { Checking Raw Materials by } \\
\text { the QC department before } \\
\text { entering the production } \\
\text { department. }\end{array}$ & 6 & 2 & 3 & 36 \\
\hline & & Tools incomplete & $\begin{array}{l}\text { Budgeting for purchasing tools } \\
\text { is expanded. }\end{array}$ & 3 & 3 & 6 & 54 \\
\hline & & The condition of the tools is not good & $\begin{array}{l}\text { Re-checking tools by the tools } \\
\text { warehouse before giving them } \\
\text { to the technician. }\end{array}$ & 3 & 3 & 3 & 27 \\
\hline & & Wrong procedure & $\begin{array}{c}\text { Double inspection is carried } \\
\text { out by the QC in the work } \\
\text { process. }\end{array}$ & 4 & 4 & 3 & 48 \\
\hline & & Poor lighting & Portable lights are reproduced. & 2 & 2 & 3 & 12 \\
\hline
\end{tabular}

Table 5:- FMEA Sheet Result Cargo Sidewall Tear

Source: PT. GMF AeroAsia, Tbk

Example of FMEA score calculation table as follows:

In the cause of defect: Cargo Sidewall Tear

$\mathrm{RPN}=$ severity $\mathrm{x}$ occurance $\mathrm{x}$ detection

$=7 \times 5 \times 5$

$=175$

After analysis using the FMEA method by technician 1 (Airframe Powerplant), technician 2 (Composite Expert) and supervisors, the highest rating of severity, occurance, and detection of cause of failure are used as references and the RPN value is calculated. The lowest RPN value is low lighting (12) and the highest RPN value is lack of Skill \& Knowlage (175).

Re-analyzed as a basis for improvement using the 5 why's method.

Problem: The discovery of the Cargo Sidewall Tear in the Cargo Compartment restoration process.

1. Why 1: Why the discovery of the Cargo Sidewall Tear?

Answer: Because Cargo Sidewall is unable to support the load.

2. Why 2: Why Cargo Sidewall is unable to support the load?

Answer: Because the Fastener is not installed correctly.
3. Why 3: Why the Fastener is not installed correctly? Answer: Because the installation method is wrong.

4. Why 4: Why is the installation wrong?

Answer: Because technicians lack Skill \& Knowlage

5. Why 5: Why do technicians lack skill \& knowlage?

Answer: Because the technicians haven't done the training.

6. Why 6: Why hasn't the technician done the training?

Answer: Because there is no training scheduling

From this analysis it can be concluded that the Lack of Skill and Knowlage caused by the absence of training scheduling is the root cause of damage to the Cargo Sidewall Tear. Therefore it is necessary to improve using the $5 \mathrm{~W}+1 \mathrm{H}$ method.

\section{- Control}

This stage is the fifth and final stage in the DMAIC method, which at this stage provides suggestions or recommendations for improvement so that the company is consistent with the company's quality commitments so that the same problem does not occur again in the future. 
In the previous phase, Cause of Failure was found, namely Lack of Skill \& Knowlage, then an analysis of improvements was made using the $5 \mathrm{~W}+1 \mathrm{H}$ method and the results of the improvement analysis were found:

- "What" What are the improvement plans?

Provide scheduled training to new technicians and mentoring in the field.

- "Why" Why do improvements need to be done?

In order to transfer knowlage and add skills

- "Where" Where do repairs need to be done?

Improvements were made in the production learning services unit
- "When" When were the repairs made?

Training and mentoring is done for 6 months when doing maintenance

- "Who" Who is responsible for the improvement?

In charge is the Learning Services unit

- "How" How do you make these improvements?

Scheduling Training for knowledge provisioning, after doing training, mentoring is done for 6 months in the field. This proposal aims to increase the Skill and Knowlage of the technician.

\begin{tabular}{|c|c|c|}
\hline DMAIC & Tools & Value \\
\hline Define & SIPOC Diagram & $\begin{array}{l}\text { Improved process flow from the Cargo Sidewall from suppliers, inputs, processes, } \\
\text { outputs to customers. }\end{array}$ \\
\hline Measure & Diagram Parreto & The biggest damage was Cargo Sidewall Tear with a percentage of $51 \%$ \\
\hline Analyze & Fishbone Diagram & $\begin{array}{l}\text { Factors causing the Cargo Sidewall Tear come from man, machine, method, } \\
\text { material, environment. }\end{array}$ \\
\hline \multirow{2}{*}{ Improve } & FMEA & The highest RPN score of 175 in rank 1 is Lack of skill \& Knowlage \\
\hline & 5 why's & $\begin{array}{l}\text { Lack of Skill and Knowlage due to lack of training scheduling is the root cause of } \\
\text { damage to Cargo Sidewaal Tear. }\end{array}$ \\
\hline Control & $5 \mathrm{~W}+1 \mathrm{H}$ & Proposed improvements for scheduled training and mentoring in the field \\
\hline
\end{tabular}

Table 6:- Result and Analysis

Source: Data Processing

\section{CONCLUSIONS}

Based on the results of research that has been done on the sidewall tear cargo component at PT. GMF AeroAsia, Tbk, the conclusions that can be drawn from this study are as follows:

$>$ Factors that cause damage to the Cargo sidewall tear are man, material, machine, method and environment. After analyzing using FMEA (Failure Mode and Effect Analysis) at the stage of improving the greatest risk level of the Cargo Sidewall tear repair process is Leak of Skill and Knowledge. These factors cause the installation of cargo sidewall in the cargo compartment restoration process not installed perfectly, so that when given a load will cause the Cargo Sidewall to be easily torn (tear).

The proposed improvements that can be done to make the process of repairing the Cargo Sidewall tear component based on the largest RPN (Risk Priority Number) from the results of the FMEA (Failure Mode and Effect Analysis) analysis and further analysis using the $5 \mathrm{~W}+1 \mathrm{H}$ method as follows: 1 . Conduct Training Scheduling to technicians related to how to properly install cargo sidewall. This training aims to improve basic knowledge about aircraft specifically cargo compartment. This scheduling must be done by the Production Learning Services unit. 2. Conduct a mentoring program in the field after doing classroom training. Where this mentoring is based points to improve skills on the field. The mentors come from experienced seniors in the field who have Boeing 737800 aircraft certificates.

\section{REFERENCES}

[1]. T. D. Caesaron, "Penerapan Metode Six Sigma dengan Pendekatan DMAIC Pada Proses Handling Painted Body BMW X3 (Studi Kasus: PT. Tjahja Sakti Motor)," vol. IX, no. 3, pp. 248-256, 2015.

[2]. L. R. P. . Higgins, Maintenance Engineering Handbook, 6th ed. New York: McGraw-Hill Companies Inc, 2002.

[3]. F. . Breyfogle, Implementing Six Sigma, 2nd ed. New Jersey: John Wiley \& Son, Inc., 2003.

[4]. GE, "What is six sigma: the roadmap to customer impact," pp. 1-5, 2013, [Online]. Available: http://www.ge.com/sixsigma/SixSigma.pdf.

[5]. C. Kenneth, "Costumer Focused Development with QFD," 2002, [Online]. Available: https://www.scribd.com/document/249703290/Custo mer-focused-Development-With-QFD-by-KennethCrow.

[6]. M. . Nasution, Manajemen Mutu Terpadu: Total Quality Management, 2nd ed. Bogor: Ghalia Indonesia, 2005. 
[7]. D. W. Ariani, Pengendalian Kualitas Statistik. Yogyakarta: Andi, 2004.

[8]. S. A. Majid and E. P. D. Warpani, Ground Handling: Manajemen Pelayanan Darat Perusahaan Penerbangan. Depok: Rajawali Pers, 2009.

[9]. Sugiyono, Bussines Research Method. Bandung: Alfabeta, 2012.

[10]. A. Syukron and M. Kholil, SIX SIGMA Quality For Business Improvement. Yogyakarta: Graha Ilmu, 2013.

[11]. E. Rimawan, M. Kholil, and S. Fachira, "Analysis Quality Control of Garnish Back Door License in Injection Molding Process Using DMAIC Method and VSM Method at PT . Suzuki Indomobil Motor," vol. 7, no. 6B, pp. 19-31, 2019, doi: 10.13189/ujme.2019.071504. 